\title{
Influence of the $\mathrm{K}^{+}$and $\mathrm{Ca}^{2+}$ on the Presence of Sugars in the Phloem, and Growth Parameters in Capsicum
}

\author{
Pedro Alberto Rojas-Rojas ${ }^{1}$, Saul Parra-Terraza ${ }^{2}$, Sixto Velarde-Felix ${ }^{3}, \&$ Luis Alberto Lightbourn-Rojas ${ }^{1}$ \\ ${ }^{1}$ Instituto Lightbourn, Cd. Jimenez, México \\ ${ }^{2}$ Facultad de Agronomía, Universidad Autonoma de Sinaloa, Culiacán, México \\ ${ }^{3}$ Departamento de Biología Molecular, Instituto Nacional de Investigaciones Forestales, agrícolas y Pecuarias, \\ Culiacán, México
}

Correspondence: Luis Alberto Lightbourn-Rojas, Instituto Lightbourn, Cd. Jimenez, CHI., CP 33980, México. Tel: 1-629-542-5101. E-mail: drlightbourn@institutolightbourn.edu.mx

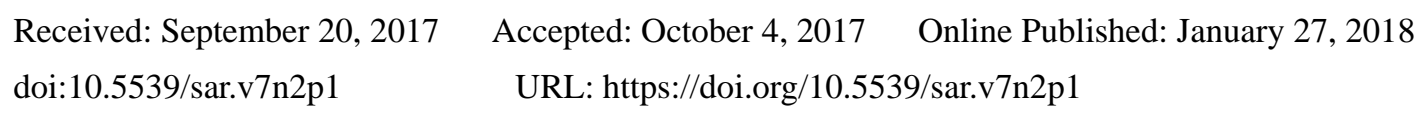

\begin{abstract}
The effect of various $\mathrm{K}^{+}$and $\mathrm{Ca}^{2+}$ nutrient solutions were evaluated to measure the growth rate, amount of reducing sugars and the production of Capsicum annuum Plants were grown directly in soil under shade house conditions in two separate experiments across two consecutive years. Nine nutrient solutions containing three levels of $\mathrm{K}+(27,35$ and $43 \%)$ combined with three levels of $\mathrm{Ca}^{2+}(37,45$ and $53 \%)$ were used, along with the Steiner solution treatment as a control. Irrigation was calculated every week according to Kc, volumetric humidity and ETo, the experimental design was a block (furrows) with a 3(x)3 factorial arrangement. There was no interaction between growth rate, sugars and yield. Plants treated with the combination $27 \%$ of potassium with $53 \%$ of calcium presented a yield of $500 \mathrm{~g} /$ fruit greater than the control treatment (Steiner), and produced on average 2 more fruits per plant with a weight of $160 \mathrm{~g} /$ fruit $(<0.05)$ higher than Steiner, the low potassium concentration $(27 \%$ ) induced a lower concentration of sugars with a value $>3 \mathrm{mg} / \mathrm{ml}$ during the first crop cycle, it were analyzed during the flowering stage, and in the second agricultural cycle, during the fruiting stage it was < $4 \mathrm{mg} / \mathrm{ml}$.
\end{abstract}

Keywords: glucose, fructose, chili, yield, plant nutrition

\section{Introduction}

México is the second largest world producer of Capsicum annuum, with 2,131,740 tonnes annually. In Mexico, bell pepper is produced mainly in the northwestern and part of the central regions, with a national production of 206,227 tons, of which Sinaloa contributes 175,694 tons, or $86 \%$ of the national total. Plant nutrition is determinant to increase yields, however, nutrient excess causes contamination of soils and waters (Oliveira et al., 2013) and the actual tendency is to replace traditional methods of nutrition for more sustainable management techniques on profitable crops, especially horticultural crops grown in protected systems (Khan and Shah, 2011; Nunes-Júnior et al., 2017).

Pepper growth and development is determined in phenological stages (USDA, 2003, Moreno et al., 2011). The addition of fertilizers is required, stating from its establishment (Kant et al., 2005). This is commonly achieved by fertigation to obtain a well developed and high quality plant (Royo et al., 1998), with increased yields (Parra-Terraza et al., 2008). Fertilizers influences quality parameters such as glucose and fructose (Lester et al., 2010).

Potassium $\mathrm{K}^{+}$is absorbed mainly in roots (Maathuis and Sanders, 1994). The absorption is more common in ionic form of inorganic sources and mainly monovalent elements (Frageria, 2013; Mengutay et al., 2013), $\mathrm{K}^{+}$ Participates in physiological functions, such as $\mathrm{pH}$ regulation and osmotic regulation of plants. It also participates in the fixation of atmospheric $\mathrm{N}_{2}$ in legumes due to its capacity to recycle soil $\mathrm{K}^{+}$(Giacomini et al., 2003), storage and transport of assimilates to opening and closure stoms by means of increased $\mathrm{K}^{+}$in the guard cells, The absorption of water from the cells gards increases the turgidity of the cell to stomatal opening (Kant $e t$ al., 2005; Rending and Taylor, 1989).

Adequate $\mathrm{K}^{+}$level of reduces the attack of fungi, bacteria, viruses and nematodes on plants mainly by synthesis 
of jasmonates and glucosylonates (Datnoff et al., 2007; Zörb et al., 2014), accumulation of leaf sugars Makes it more palatable for some insects, and bacteria could enter by stomata under $\mathrm{K}^{+}$starvation (Melotto et al., 2006). The absence of $\mathrm{K}^{+}$in the nutrient solution causes an increase in the rest of cations balancing the ionic content of the cell (Menguel and Kirkby, 1980) also increases of sugars in leaves, and could replacing osmotic molecules (Zörb et al., 2014).

Calcium $\mathrm{Ca}^{2+}$, is one of the essential elements for plant growth and fruit development (McLaughlin and Wimmer, 1999) and its functions in plant nutrition are well documented (Mengel \& Kirkby, 1987; Marschner, 1995; Saure, 2001, Taylor and Locascio, 2004, Villegas et al., 2005).

Apical rot (BER) is the common physiological disorder in crops (Frost and Kretchman, 1989). BER worldwide causes losses of up to 50\% of production (Taylor and Locascio, 2004). Because BER fruits have significantly less $\mathrm{Ca}^{2+}$ than normal fruits, it has been considered that the main cause of BER is a $\mathrm{Ca}^{2+}$ shortage in the fruit (Shear, 1975; Adams and Ho, 1993; Wien 1999).

Grower of protected crops systems (shade-house and greenhouse) in Sinaloa, Mexico, use $\mathrm{Ca}^{2+}$ higher doses, than crop requirements with nutrient solutions concentrated or unbalanced, so their nutrients can be harmful to the environment, generate pollution by pouring the washing fractions into the soil (Kakuturu et al., 2013).

The objective of the present study was to evaluate the effect of different concentrations of $\mathrm{Ca}^{2+}$ and $\mathrm{K}^{+}$on the Nutrient Solution and their interaction on the production of sugars, mineral composition and performance pepper grown in shade.

\section{Materials and Methods}

The average rainfall per year is around $700 \mathrm{~mm}$, precipitation occurring in summer and only $5 \%$ in winter. The average annual temperature is $25.9^{\circ} \mathrm{C}$ that gives a climate classified as BS1 ('h) w (w) (e) according to KOPPEN and modified by García (2004). The soil of the experimental site is classified as chromic vertisol (FAO, 2007), with the following chemical characteristics: table 1. (AOAC, 1998).

Table 1. Effect of $\mathrm{K}^{+}$and $\mathrm{Ca}^{2+}$ interaction on nutrient solution for plant Height (H), Stem Diameter (ST), Total Weight (TW), Leaf Dry Weight (LDW) Stem Dry Weight (SDW)

\begin{tabular}{ccccccccc}
\hline $\mathrm{pH}$ & $\mathrm{MO} \%$ & $\mathrm{~N} \mathrm{ppm}$ & $\mathrm{P} \mathrm{ppm}$ & $\mathrm{K} \mathrm{ppm}$ & $\mathrm{Na} \mathrm{ppm}$ & $\mathrm{Ca} \%$ & $\mathrm{Mg} \%$ & $\mathrm{CIC}$ \\
\hline 8.3 & 0.74 & 20.9 & 9.0 & 959 & 586 & 1.14 & 0.19 & 1.2 \\
\hline
\end{tabular}

The study was divided in two agricultural cycles, the first one were 9 treatments evaluated and conducted from October $5^{\text {th }}, 2014$ to May $20^{\text {th }}, 2015$. After that first experiment, were replicated the secod with the three best treatments from the first experiment, and these were replicated in the 2015-2016 the next agricultural cycle, it was inside a shade house of two acres, located in the facilities of the National Institute of Agricultural Research, in the municipality of Culiacán, México, $\left(24^{\circ} 63^{\prime} \mathrm{N}\right.$ and $107^{\circ} 44^{\prime} \mathrm{O}$, and 22 (MASL).

The pepper seed used in both agricultural cycles was "Botaros (1010)" (Zeraim-Geddera) ® variety, germinated in a greenhouse and transplanted 45 days after germination, Nine nutrient solutions at $50 \%$ concentration were prepared and applied during the first 15 days after transplanting, and the concentrations were increased to $100 \%$ from there to the end of the experiment. Nutrient solutions were adjusted to an osmotic potential of $-0.072 \mathrm{Mpa}$. The concentrations of $\mathrm{K}^{+}, \mathrm{Ca}^{2+}$ and $\mathrm{Mg}^{2+}$ remained constant (Steiner, 1984; Parra-Terraza et al., 2012), maintaining constant concentrations of $\mathrm{NO}_{3}{ }^{-}, \mathrm{H}_{2} \mathrm{PO}_{4}{ }^{-}$and $\mathrm{SO}_{4}{ }^{2-}$ (Ramírez et al., 2010).

Table 2. Effect of $\mathrm{K}^{+}$and $\mathrm{Ca}^{2+}$ interaction on nutrient solution for plant Height (H), Stem Diameter (ST), Total Weight (TW), Leaf Dry Weight (LDW) Stem Dry Weight (SDW)

\begin{tabular}{cccccccccc}
\hline Factor & \multicolumn{1}{c}{ Growth readings at harvest of pepper culture } \\
\hline$\% \mathrm{~K}$ & \multicolumn{1}{c}{27} & \multicolumn{1}{c}{35} & \multicolumn{4}{c}{43} \\
\hline$\% \mathrm{Ca}$ & 37 & 45 & 53 & 37 & 45 & 53 & 37 & 45 & 53 \\
$\mathrm{H} \mathrm{cm}$ & $130^{\mathrm{a} \mathrm{b}^{*}}$ & $127^{\mathrm{ab}}$ & $136^{\mathrm{a}}$ & $120^{\mathrm{ab}}$ & $131^{\mathrm{ab}}$ & $115^{\mathrm{ab}}$ & $123^{\mathrm{ab}}$ & $109^{\mathrm{b}}$ & $111^{\mathrm{ab}}$ \\
ST mm & $13.4^{\mathrm{ab}}$ & $13.3^{\mathrm{ab}}$ & $13.6^{\mathrm{a}}$ & $13.1^{\mathrm{ab}}$ & $13.7^{\mathrm{a}}$ & $12.7^{\mathrm{ab}}$ & $13.2^{\mathrm{ab}}$ & $12.8^{\mathrm{ab}}$ & $12.2^{\mathrm{b}}$ \\
TW gr & $77.8^{\mathrm{a}}$ & $69.4^{\mathrm{ab}}$ & $74.0^{\mathrm{a}}$ & $65.7^{\mathrm{ab}}$ & $66.4^{\mathrm{ab}}$ & $70.4^{\mathrm{ab}}$ & $67.3^{\mathrm{ab}}$ & $64.1^{\mathrm{ab}}$ & $58.6^{\mathrm{b}}$ \\
LDW gr & $26.7^{\mathrm{a}}$ & $23.1^{\mathrm{ab}}$ & $22.2^{\mathrm{ab}}$ & $22.4^{\mathrm{ab}}$ & $20.4^{\mathrm{ab}}$ & $26.0^{\mathrm{a}}$ & $21.3^{\mathrm{ab}}$ & $21.5^{\mathrm{ab}}$ & $17.5^{\mathrm{b}}$ \\
SDW gr & $43.0^{\mathrm{a}}$ & $39.3^{\mathrm{ab}}$ & $43.8^{\mathrm{a}}$ & $35.3^{\mathrm{ab}}$ & $38.1^{\mathrm{ab}}$ & $36.2^{\mathrm{ab}}$ & $38.0^{\mathrm{ab}}$ & $34.6^{\mathrm{ab}}$ & $33.1^{\mathrm{b}}$ \\
\hline
\end{tabular}

*Within columns means with the same letter are not significantly different $(\mathrm{P}>0.05)$. 
Nine nutrient solutions were defined, at three levels of $\% \mathrm{~K}^{+}\left(27,35\right.$, and 43), with three levels of $\% \mathrm{Ca}^{+2}(37,45$, and 53), these nine nutrient solutions were applied simultaneously in four replicates inside the shade house to account as a blocks.

Irrigation was applied every morning at 06:00 am, adjusting the volume of water 35.75\% less, than the account

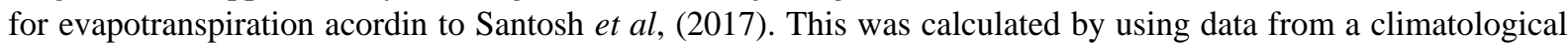
station of the National Water Commission (A'fifah et al., 2015).

The evaluation of growth variables consisted of measuring plant height, stem diameter and leaf area (De Swart et al., 2004), Once the growth variables were evaluated, the plants were dissected to partition leaves and stems for chemical analysis and determine the concentration of $\mathrm{N}, \mathrm{P}, \mathrm{K}, \mathrm{Ca}$ and $\mathrm{Mg}$, according to the methodologies proposed by Motsara and Roy (2008), these mineral composition were analized at harvest stage. The total of moisture were of 10 plants per treatment on each block, for a total of 360 plants sampled.

Plants were harvested when the fruit reached physiological maturity at 85 days after planting (DAP). The fruits collected were classified for quality as marketable fruits in agreement with USDA (2003), and fruits not meeting adequate quality standards were not included in the yield measurements. Measurements for reducing sugars were determined at two points, $33 \mathrm{ddp}$ and $100 \mathrm{ddp}$, corresponding to the first cycle and second cycle of flowering, respectively, as described by Gross (1982) and Koch (1996).

The experimental design for grown variables were a block (furrows) with a $3(\mathrm{x}) 3$ factorial arrangement, according to the mineral composition of nine nutrition solitions of three levels of $\% \mathrm{~K}^{+}(27,35$, and 43$)$, with three levels of $\% \mathrm{Ca}^{+2}(37,45$, and 53), these nine nutrient solutions were applied simultaneously as a treatments, the total of plant evaluated for moisture were of 10 plants in four replicates inside the shade house to account as blocks, resulting in a total of 360 plants sampled. The analysis of variance included main factors and interactions with a significance threshold level of $\alpha=0.05$, was carried out using SAS software were used for the statistical analyses (Statistical Analysis System, version 8.2, SAS Institute, Cary, N.C., USA).

\section{Results and Discussion}

Plant height, stem diameter and total weight showed a larger increase in plants treated with the $\mathrm{K}^{+} / \mathrm{Ca}^{2+}$ ratio: $27 / 53$, and the lowest height was recorded in a plant treated with the $\mathrm{K}^{+} / \mathrm{Ca}^{2+}$ ratio: $43 / 45$ (Table 2). This indicates that a high potassium dose competes with calcium absorption and therefore retards cell growth and plant development (Ramírez et al., 2010). High dose salt concentrations may also explain the slow development since they can cause toxicity (Karimi et al., 2009). In the presence of high salt content, the stem diameter and plant weight were observed, indicating stress due to plant competition for nutrients (Zúñiga-Estrada et al., 2004).

As shown in Table 3, the nutrient treatment of potassium and calcium at a ratio of 27/53 resulted in plants with the highest growth indicators, confirming the fact that it is not necessary to apply high doses of fertilizer to obtain optimal growth. Parra-Terraza et al. (2012) also note that an increase of $\mathrm{Ca}^{2+}$ in the nutrient solution is not reflected in production but only in tissue analysis. The mineral content being higher in the treatments whit high dose on agrees with Turkment et al. (2008) who reported lower K content in the control that showed the lowest quality of chili plant, independent of the source of potassium (Chapagain et al., 2003). Flores et al. (2004) report that increasing the concentration of $\mathrm{Ca}^{2+}$ in the growth medium increased hydrophilic antioxidante activity in pepper, that are associated with a larger stem diameter. The ratio $\mathrm{K}^{+} / \mathrm{Ca}^{2+}: 27 / 53$ in this work was the treatment of higher content of $\mathrm{CaNO}_{3}$ in proportion to the other treatments. 
Table 3. Effect of $\mathrm{K}^{+}$and $\mathrm{Ca}^{2+}$ interaction on nutrient solution for analysis mineral of leaf and stem pepper plants

\begin{tabular}{cccccccccc}
\hline Factor & \multicolumn{8}{c}{ Percentage of nutrient in leaf dry matter } \\
\hline$\% \mathrm{~K}$ & \multicolumn{1}{c}{37} & \multicolumn{7}{c}{$c$} & 43 \\
\hline$\% \mathrm{Ca}$ & 37 & 45 & 53 & 37 & 45 & 53 & 37 & 45 & 53 \\
$\% \mathrm{~N}$ & $2.22^{\mathrm{bc}}$ & $2.29^{\mathrm{abc}}$ & $2.29^{\mathrm{abc}}$ & $2.32^{\mathrm{abc}}$ & $2.52^{\mathrm{a}}$ & $2.47^{\mathrm{ab}}$ & $2.24^{\mathrm{abc}}$ & $2.26^{\mathrm{abc}}$ & $2.07^{\mathrm{a}}$ \\
$\% \mathrm{P}$ & $0.52^{\mathrm{b}}$ & $0.64^{\mathrm{ab}}$ & $0.62^{\mathrm{ab}}$ & $0.59^{\mathrm{b}}$ & $0.61^{\mathrm{ab}}$ & $0.73^{\mathrm{a}}$ & $0.53^{\mathrm{b}}$ & $0.55^{\mathrm{b}}$ & $0.60^{\mathrm{ab}}$ \\
$\% \mathrm{~K}$ & $4.49^{\mathrm{b}}$ & $4.96^{\mathrm{ab}}$ & $5.12^{\mathrm{ab}}$ & $4.77^{\mathrm{ab}}$ & $4.36^{\mathrm{b}}$ & $4.81^{\mathrm{ab}}$ & $5.41^{\mathrm{a}}$ & $5.09^{\mathrm{ab}}$ & $5.36^{\mathrm{a}}$ \\
$\% \mathrm{Mg}$ & $0.86^{\mathrm{ab}}$ & $0.92^{\mathrm{ab}}$ & $0.99^{\mathrm{a}}$ & $0.95^{\mathrm{ab}}$ & $0.83^{\mathrm{b}}$ & $0.99^{\mathrm{a}}$ & $0.90^{\mathrm{ab}}$ & $0.94^{\mathrm{ab}}$ & $0.88^{\mathrm{ab}}$ \\
$\% \mathrm{Ca}$ & $3.12^{\mathrm{ab}}$ & $3.24^{\mathrm{ab}}$ & $3.63^{\mathrm{a}}$ & $3.59^{\mathrm{ab}}$ & $2.96^{\mathrm{ab}}$ & $3.27^{\mathrm{ab}}$ & $3.05^{\mathrm{ab}}$ & $3.28^{\mathrm{ab}}$ & $2.95^{\mathrm{b}}$ \\
\hline \multicolumn{8}{c}{ Percentage of nutrient in dry matter basis of stems } \\
\hline$\% \mathrm{~N}$ & $0.79^{\mathrm{cd}}$ & $0.86^{\mathrm{bcd}}$ & $0.86^{\mathrm{bcd}}$ & $0.98^{\mathrm{ab}}$ & $0.95^{\mathrm{bc}}$ & $1.03^{\mathrm{a}}$ & $0.92^{\mathrm{abc}}$ & $0.86^{\mathrm{bcd}}$ & $0.72^{\mathrm{c}}$ \\
$\% \mathrm{P}$ & $0.18^{\mathrm{a}}$ & $0.19^{\mathrm{a}}$ & $0.24^{\mathrm{a}}$ & $0.22^{\mathrm{a}}$ & $0.22^{\mathrm{a}}$ & $0.31^{\mathrm{a}}$ & $0.33^{\mathrm{a}}$ & $0.32^{\mathrm{a}}$ & $0.24^{\mathrm{a}}$ \\
$\% \mathrm{~K}$ & $2.30^{\mathrm{a}}$ & $2.27^{\mathrm{a}}$ & $2.88^{\mathrm{a}}$ & $2.81^{\mathrm{a}}$ & $2.54^{\mathrm{a}}$ & $3.17^{\mathrm{a}}$ & $2.66^{\mathrm{a}}$ & $2.93^{\mathrm{a}}$ & $2.60^{\mathrm{a}}$ \\
$\% \mathrm{Mg}$ & $0.51^{\mathrm{a}}$ & $0.44^{\mathrm{a}}$ & $0.59^{\mathrm{a}}$ & $0.60^{\mathrm{a}}$ & $0.54^{\mathrm{a}}$ & $0.56^{\mathrm{a}}$ & $0.52^{\mathrm{a}}$ & $0.59^{\mathrm{a}}$ & $0.55^{\mathrm{a}}$ \\
$\% \mathrm{Ca}$ & $0.95^{\mathrm{a}}$ & $0.89^{\mathrm{a}}$ & $1.02^{\mathrm{a}}$ & $1.06^{\mathrm{a}}$ & $1.01^{\mathrm{a}}$ & $1.02^{\mathrm{a}}$ & $0.95^{\mathrm{a}}$ & $1.13^{\mathrm{a}}$ & $0.99^{\mathrm{a}}$ \\
\hline
\end{tabular}

*Within columns means with the same letter are not significantly different $(\mathrm{P}>0.05)$.

The fruit yield in the first year was 21-25 fruits per plant. Although there was no statistically significant difference for the number of fruits, it is similar to the studies of Oliveira et al., 2013 and Nunes-Júnior et al., 2017, who obtained 20 And 24 fruits in their best treatment respectively, the yield was $3.2-4.2 \mathrm{~kg} / \mathrm{plant}$, that was superior to results obtained by Azofeifa and Moreira (2005) who yielded $2.2 \mathrm{~kg} / \mathrm{plant}(0.35 \mathrm{~m} / \mathrm{plant})$ in similar conditions of management, whereas Oliveira et al. (2013) obtained $1.2 \mathrm{~kg} / \mathrm{plant}$. The yield data show an increase in second year that is coincident with Parra-Terraza et al. (2008), who evaluated different doses of calcium on yield of $\mathrm{kg} / \mathrm{plant}$ crop in two crop cycles, although in this case there is a significant difference in the $\mathrm{K}^{+} / \mathrm{Ca}^{2+}$ ratio: $27 / 53$ in year two, which may be due to the shortening of the treatments to the three best resulting from the first year to the second year. Fruit weight was 143 to $177 \mathrm{~g}$ per fruit, which coincides with Zúñiga-Estrada et al. (2004) who obtained from 41 to $188 \mathrm{~g} /$ fruit, in this respect Oliveira et al. (2013) reports a weight $54 \mathrm{~g} /$ fruit, as shown in Table 4 .

Table 4. Number of sweet pepper fruits an sugar content in leaf, based of $\mathrm{K}^{+} / \mathrm{Ca}^{2+}$ relation in the nutritrient solution

\begin{tabular}{|c|c|c|c|c|}
\hline \multirow[t]{3}{*}{ Treatments } & \multicolumn{3}{|c|}{ production components } & \multirow{3}{*}{$\begin{array}{c}\text { Reducing sugar glucose+fructose } \\
\mathrm{g} / \mathrm{L}\end{array}$} \\
\hline & \multirow{2}{*}{$\begin{array}{c}\text { Number of fruits } \\
\text { per plant }\end{array}$} & \multirow{2}{*}{$\begin{array}{c}\text { Fruit } \\
\text { weight }(\mathrm{g})\end{array}$} & \multirow{2}{*}{$\begin{array}{c}\text { fruit yield } \\
\mathrm{kg} / \text { plant }\end{array}$} & \\
\hline & & & & \\
\hline \multicolumn{5}{|l|}{ Year 1} \\
\hline $27 / 37$ & $25.5^{\mathrm{a}}$ & $142.6^{\mathrm{a}}$ & $3.62^{\mathrm{a}}$ & $28.3^{\mathrm{d}}$ \\
\hline $27 / 45$ & $23.8^{\mathrm{a}}$ & $147.0^{\mathrm{a}}$ & $3.48^{\mathrm{a}}$ & $27.9^{\mathrm{d}}$ \\
\hline $27 / 53$ & $27.1^{\mathrm{a}}$ & $154.7^{\mathrm{a}}$ & $4.18^{\mathrm{a}}$ & $30.7^{\mathrm{cd}}$ \\
\hline $35 / 37$ & $24.5^{\mathrm{a}}$ & $143.3^{\mathrm{a}}$ & $3.49^{\mathrm{a}}$ & $29.5^{\mathrm{cd}}$ \\
\hline $35 / 45$ & $24.8^{\mathrm{a}}$ & $146.2^{\mathrm{a}}$ & $3.68^{\mathrm{a}}$ & $29.0^{\mathrm{cd}}$ \\
\hline $35 / 53$ & $21.4^{\mathrm{a}}$ & $146.2^{\mathrm{a}}$ & $3.16^{\mathrm{a}}$ & $28.9^{\text {acd }}$ \\
\hline $43 / 37$ & $23.2^{\mathrm{a}}$ & $143.0^{\mathrm{a}}$ & $3.32^{\mathrm{a}}$ & $33.3^{\mathrm{bc}}$ \\
\hline $43 / 45$ & $23.5^{\mathrm{a}}$ & $142.8^{\mathrm{a}}$ & $3.37^{\mathrm{a}}$ & $38.3^{\mathrm{a}}$ \\
\hline $43 / 53$ & $23.1^{\mathrm{a}}$ & $142.0^{\mathrm{a}}$ & $3.27^{\mathrm{a}}$ & $35.8^{\mathrm{ab}}$ \\
\hline \multicolumn{5}{|l|}{ Year 2} \\
\hline $27 / 37$ & $35.5^{\mathrm{a}}$ & $163.7^{\mathrm{a}}$ & $5.82^{\mathrm{ab}}$ & $41.3^{\mathrm{a}}$ \\
\hline $27 / 45$ & $37.0^{\mathrm{a}}$ & $168.8^{\mathrm{a}}$ & $6.24^{\mathrm{ab}}$ & $38.7^{\mathrm{ab}}$ \\
\hline $27 / 53$ & $39.4^{\mathrm{a}}$ & $177.2^{\mathrm{a}}$ & $6.98^{\mathrm{a}}$ & $36.4^{\mathrm{b}}$ \\
\hline $35 / 45$ & $33.7^{\mathrm{a}}$ & $160.3^{\mathrm{a}}$ & $5.39^{\mathrm{b}}$ & $37.2^{b}$ \\
\hline
\end{tabular}

*Within columns means with the same letter are not significantly different $(\mathrm{P}>0.05)$.

Reducing sugars (glucose + fructose) analyzed in plants from year one showed a trend of lower concentration in low doses of $\mathrm{K}^{+}$throughout the stages of development with values ranging from 28-38 g/L which coincides with Flores et al (2004) who obtained values of $29-32 \mathrm{~g} / \mathrm{L}$ with no significant difference, also the author report a 
strong relationship of sugars with the production of antioxidants, this trend may be due to producing antioxidants in fruits with more sugar (Lester et al., 2010), which means a better use of sugars In the production of fruit (Ramírez et al., 2010). In the second year, it was confirmed that the $\mathrm{K}^{+} / \mathrm{Ca}^{2+}$ treatment, 27/53, showed the lowest sugar content during the production stage, which coincides with Rolland et al. (2006), who mention that sugars play an important role in plant regulatory functions and can accumulate if necessary. The highest fruit yield was obtained by this treatment, indicating that the low dose of potassium is sufficient to obtain the production potential (Nunes-Júnior et al., 2017).

The number of marketable fruits evaluated showed only a significant difference in the median size, however, the average fruit weight was $175 \mathrm{~g}$ as shown in Table 5. Oliveira et al. (2013) reported an average weight of $51 \mathrm{~g}$ per fruit, Zúñiga-Estrada et al. (2004) reported fruits of Quality 1, which varied from $112 \mathrm{~g}$ to $188 \mathrm{~g}$, fruits of Quality 2 varied from 65 to $133 \mathrm{~g}$, and Quality 3, from 41 to $71 \mathrm{~g}$ per fruit, respectively.

Table 5. Number of marketable fruits evaluated based on $\mathrm{K}^{+} / \mathrm{Ca}^{2+}$ relation on nutritrient solution

\begin{tabular}{|c|c|c|c|c|}
\hline \multirow{3}{*}{ Treatments } & \multicolumn{4}{|c|}{ Percentage of fruit according to quality } \\
\hline & Extra large & Large & Medium & Small \\
\hline & $<250 \mathrm{~g}$. & $200-249 \mathrm{~g}$. & 150-199 g. & $>99 \mathrm{~g}$. \\
\hline \multicolumn{5}{|l|}{ Year 1} \\
\hline $27 / 37$ & $8.0^{\mathrm{a}^{*}}$ & $20.1^{\mathrm{a}}$ & $36.6^{\mathrm{ab}}$ & $35.3^{\mathrm{a}}$ \\
\hline $27 / 45$ & $2.8^{\mathrm{a}}$ & $19.3^{\mathrm{a}}$ & $45.2^{\mathrm{a}}$ & $32.7^{\mathrm{a}}$ \\
\hline $27 / 53$ & $7.5^{\mathrm{a}}$ & $21.2^{\mathrm{a}}$ & $41.3^{\mathrm{ab}}$ & $30.0^{\mathrm{a}}$ \\
\hline $35 / 37$ & $5.7^{\mathrm{a}}$ & $19.0^{\mathrm{a}}$ & $41.3^{\mathrm{ab}}$ & $34.0^{\mathrm{a}}$ \\
\hline $35 / 45$ & $5.7^{\mathrm{a}}$ & $23.1^{\mathrm{a}}$ & $34.5^{\mathrm{ab}}$ & $36.7^{\mathrm{a}}$ \\
\hline $35 / 53$ & $7.6^{\mathrm{a}}$ & $24.3^{\mathrm{a}}$ & $32.4^{\mathrm{b}}$ & $35.7^{\mathrm{a}}$ \\
\hline $43 / 37$ & $4.1^{\mathrm{a}}$ & $20.4^{\mathrm{a}}$ & $36.6^{\mathrm{ab}}$ & $38.9^{\mathrm{a}}$ \\
\hline $43 / 45$ & $6.5^{\mathrm{a}}$ & $18.2^{\mathrm{a}}$ & $35.8^{\mathrm{ab}}$ & $39.5^{\mathrm{a}}$ \\
\hline $43 / 53$ & $5.3^{\mathrm{a}}$ & $19.3^{\mathrm{a}}$ & $37.1^{\mathrm{ab}}$ & $38.3^{\mathrm{a}}$ \\
\hline \multicolumn{5}{|l|}{ Year 2} \\
\hline $27 / 37$ & $10.6^{\mathrm{a}}$ & $25.3^{\mathrm{a}}$ & $36.6^{\mathrm{a}}$ & $27.4^{\mathrm{a}}$ \\
\hline $27 / 45$ & $10.7^{\mathrm{a}}$ & $23.5^{\mathrm{a}}$ & $36.7^{\mathrm{a}}$ & $29.0^{\mathrm{a}}$ \\
\hline $27 / 53$ & $9.1^{\mathrm{a}}$ & $25.5^{\mathrm{a}}$ & $37.0^{\mathrm{a}}$ & $28.3^{\mathrm{a}}$ \\
\hline $35 / 45$ & $10.0^{\mathrm{a}}$ & $24.3^{\mathrm{a}}$ & $36.7^{\mathrm{a}}$ & $29.0^{\mathrm{a}}$ \\
\hline
\end{tabular}

*Within columns means with the same letter are not significantly different $(\mathrm{P}>0.05)$.

\section{Conclusions}

-Variation of potassium concentrations caused different responses in growth variables, the low dose of potassium was the best, which translates to cost savings on fertilizers. While with calcium, no significant differences were observed in the variables evaluated.

-From the yield measurements, it is deduced that there is higher productivity with the low dose of potassium, compared to that obtained with the control, Steiner solution.

-Analysing reducing sugars could offers a fast, and cheap indicator of the plant's nutritional state but its necesary to continue the experiemnts to achieve beter results.

\section{References}

A'fifah, A. R., Ismail, M. R., Puteri, E. M. W., Abdullah, S. N. A., Berahim, Z., Bakhtiar, R., \& Kausar, H. (2015). Optimum fertigation requirement and crop coefficients of chilli (Capsicum annuum) grown in soilless medium in the tropic climate. International Journal of Agriculture and Biology, 17(1), 80-88.

AOAC [Association of Official Analytical Chemists], (1998). Official methods of analysis. 14 th ed. Association of analytical chemists. Washington D. C., EEUU.

Azofeifa, Á., \& Moreira, M. A. (2005). Absorción y distribución de nutrimentos en la planta de chile dulce (Capsicum аппиит cv. ucr 589) en Alajuela, Costa-rica. Agronomía Costarricense, 29(1), 77-84.

Chapagain, B. P., Wiesman, Z., Zaccai, M., Imas, P., \& Magen, H. (2003). Potassium Chloride Enhances Fruit Appearance and Improves Quality of Fertigated Greenhouse Tomato as Compared to Potassium Nitrate. Journal of Plant Nutrition, 26(3), 643-658. https://doi.org/10.1081/PLN-120017671 
De Swart, E. A. M., Groenwold, R., Kanne, H. J., Stam, P., Marcelis, L. F. M., \& Voorrips, R. E. (2004). Non-destructive estimation of leaf area for different plant ages and accessions of Capsicum annuum L. Journal of Horticultural Science and Biotechnology, 79(5), 764-770.

FAO. (2007). Base Referencial Mundial del Recurso Suelo. Informes sobre Recursos Mundiales de Suelos No. 103. Roma. Italia. $117 \mathrm{p}$.

Flores, P., Navarro, J. M., Garrido, C., Rubio, J. S., \& y Martínez, V. (2004). Influence of $\mathrm{Ca}^{2+}, \mathrm{K}^{+}$and $\mathrm{NO}_{3^{-}}$ fertilisation on nutritional quality of pepper. Journal of the Science of Food and Agriculture. F. Sci Food Agric, 84, 569-574. https://doi.org/10.1002/jsfa.1694.

García, E. (2004). Modificaciones al sistema de clasificación climática de Köppen. ISBN: 970-32-1010-4.

Gross, K. C. (1982). A rapid and sensitive spectrophotometric method for assaying polygalacturonase using 2-cyanoacetamide. HortScience, 17, 933-934.

Kant, S., Kant, P., \& Kafkafi, U. (2005). Potassium uptake by higher plants: from field application to membrane transport. Acta Hungarica, 53(4), 43-459. Budapest.

Karimi, S., Rahemi, M., Maftoun, M., \& Tavallali, V. (2009). Effects of long-term salinity on growth and performance of two pistachio (Pistacia L.) rootstocks. Australian Journal of Basic and Applied Sciences, $3(3), 1630-1639$.

Khan, M., \& y Shah, S. (2011). Agricultural Development and Associated Environmental and Ethical Issues in South Asia. Journal of Agricultural \& Environmental Ethics, 24(6), 629-644.

Koch, K. E. (1996). Carbohydrate-modulated gene expression in plants. Annual Review of Plant Physiology and Plant Molecular Biology, 47, 509-540.

Lester, G. E., Jifon, J. L., \& Makus, D. J. (2010). Impact of potassium nutrition on postharvest fruit quality: Melon (Cucumis melo L) case study. Plant and Soil, 335(1), 117-131. https://doi.org/10.1007/s11104-009-0227-3

Moreno P. E., Mora A. R., Sánchez C. F., \& García-Pérez, V. (2011). Fenología y rendimiento de híbridos de pimiento morrón (Capsicum annuum L.) cultivados en hidroponía. Revista Chapingo Serie Horticultura, Vol. XVII, Edición Especial, 2, 5-18, Estado de México.

Motsara M. R., \& y Roy, R. N. (2008). Guide to Laboratory Establishment for Plant Nutrient Analysis. FAO Fertilizer and Plant Nutrition Bulletin 19. Food and Agriculture Organization of the United Nations. pp:220.

Nunes-Júnior, E. S., Medeiros, J. F. De, Oliveira, F. D. A. De, Lima, L. A., Bezerra, F. M. S., \& Alves, R. D. C. (2017). Fertirrigação nitrogenada e potássica no cultivo do pimentão em ambiente protegido utilizando manejos de fertirrigação. Revista Brasileira de Engenharia Agrícola E Ambiental, 21(3), 186-190. https://doi.org/10.1590/1807-1929/agriambi.v21n3p186-190

Oliveira, F. de A., Duarte, S. N., Medeiros, J. F. de, Dias, N. da S., Silva, R. C. P. da, \& Lima, C. J. G. de S. (2013). Manejos da fertirrigação e doses de N e K no cultivo de pimentão em ambiente protegido. Revista Brasileira de Engenharia Agrícola e Ambiental, 17, 1152-1159. https://doi.org/10.1590/S1415-43662013001100004

Parra-Terraza, S., Villarreal-Romero, M., Sánchez-Peña, P., Corrales-Madrid, J. L., \& Hernández-Verdugo, S. (2008). Efecto del calcio y potencial osmótico de la solución nutritiva en la pudrición apical, composición mineral y rendimiento de tomate. Interciencia, 33(6), 449-456.

Parra-Terraza, S., Mendoza-Palomares, G., \& Villarreal-Romero, M. (2012). Relación nitrato/amonio/urea y concentración de potasio en la producción de tomate hidropónico. Revista Mexicana de Ciencias Agrícolas, 3(1), 113-124.

Ramírez, M. M., Trejo-Téllez, L. I., Gómez, M. F. C., \& Sánchez, G. P. (2010). La relación $\mathrm{K}^{+} / \mathrm{Ca}^{2+}$ de la solución nutritiva afecta el crecimiento y calidad postcosecha del tulipán. Revista Fitotecnia Mexicana, 33(2), 149-156.

Rojas-Rojas, y Lightbourn-Rojas. (2017). Nitrogen and Calcium Dosage in Nutrient Solutions : Effect on Fusarium Wilt , Nutrition and Yield of Tomato Plants. Global Advanced Research Journal of Agricultural Science, 6(2), 65-74.

Rolland, F., Baena-González, E., \& Sheen, J. (2006). Sugar sensing and signaling in plants: conserved and novel mechanisms. Annual Review of Plant Biology, 57, 675-709. 
Royo, A., Birchler, T., Rose, R. W., \& Pardos Minguez, M. (1998). La planta ideal: revisión del concepto, parámetros definitorios e implementación práctica. Investigación agraria. Sistemas y recursos forestales. Instituto Nacional de Investigación y Tecnología Agraria y Alimentaria (INIA).

Steiner, A. A. (1984). The universal nutrient solution. Proc. 6th Int. Congr. On Soilless Culture. pp. 633-649. International Society for Soilless Culture. Wageningen, The Netherlands. pp. 633-649.

Turkmen, O., Sensoy, S., Demir, S., \& Erdinc, C. (2008). Effects of two different AMF species on growth and nutrient content of pepper seedlings grown under moderate salt stress. African Journal of Biotechnology, 7(4), 392-396. https://doi.org/10.5897/AJB07.603

[USDA] US Department of Agriculture (2005) United States Standards for Grades of Sweet Peppers. https://www.ams.usda.gov/sites/default/files/media/Sweet_Pepper_Standard\%5B1\%5D.pdf. Accessed Dec 18, 2017 Google Scholar.

United states standards for grades of fresh bell peppers. Ed. Agricultural Marketing Service. Unites States Department of agriculture. Pp. 14.

Zúñiga-Estrada, L., Martínez-Hernández, J. J., Baca-Castillo, G. A., Martínez-Garza, A., Tirado-Torres, J. L. y Kohashi-Shibata, J. (2004). Producción de chile pimiento en dos sistemas de riego bajo condiciones hidropónicas. Agrociencia, 38, 207-218. Colegio de postgraduados. Montecillos. Edo de México.

\section{Note:}

\section{Scope and limitation}

Scope. The study covers two macronutrients which affect pepper yield, according with other authors, in particularly the pepper crop yield, soil conditions and sugar measurement. Pepper crop, the most common hybrid used in the zone, specialized for the export trade, which attributes and quality were accepted for the customer, and can used the result for other zones whith Soil system. Yield measurements demonstrate the importance of the crop in the zone of Culiacan, Mexico.

Limitations. The study will not cover the other important nutrients as $\mathrm{N}, \mathrm{Mg}, \mathrm{P}$ and $\mathrm{S}$, neither physiology of the plant features such as flowering and root traits. Fertility of soil is an important consideration in any agricultural system. In general we have fertile soils in the primary production areas for chili peppers, thus the response of the plant was only measured by mineral plant analysis and parametric scales. PCR identification of ionic channels activated and their response to calcium and potassium were not considered.

\section{Copyrights}

Copyright for this article is retained by the author(s), with first publication rights granted to the journal.

This is an open-access article distributed under the terms and conditions of the Creative Commons Attribution license (http://creativecommons.org/licenses/by/3.0/). 